\title{
Tissue Donor Suitability
}

National Cancer Institute

\section{Source}

National Cancer Institute. Tissue Donor Suitability. NCI Thesaurus. Code C159527.

Determination that a potential donor is healthy and medically fit to proceed with the donation process. 